Original article

\title{
Effect of plant age, temperature and rainfall on Lepidoptera insect pests collected with light traps in a Eucalyptus grandis plantation in Brazil
}

\author{
Fernando AZEVEDO DE FreITAS ${ }^{\mathrm{a}}$, Teresinha VinHA ZANUNCIO ${ }^{\mathrm{b}}$, José COLA ZANUNCIO ${ }^{\mathrm{b} *}$, \\ Patrícia MARLUCi DA CONCEIÇÃo ${ }^{\mathrm{b}}$, Maria do Carmo QuEIROZ FIALHO ${ }^{\mathrm{b}}$, Aline SALES BERNARDINO ${ }^{\mathrm{b}}$ \\ a Departamento de Fitotecnia, Universidade Federal de Viçosa, 36571-000, Viçosa, State of Minas Gerais, Brazil \\ b Departamento de Biologia Animal/BIOAGRO, Universidade Federal de Viçosa, 36571-000, Viçosa, State of Minas Gerais, Brazil
}

(Received 29 August 2003; accepted 19 April 2004)

\begin{abstract}
Lepidopterous species were monitored using light traps between August 1991 and July 1996 in a Eucalyptus grandis plantation in the Municipality of Nova Era, State of Minas Gerais, Brazil. A total of 1.385 species of Lepidoptera were collected including 14 major pest species and 14 species of lesser importance. These two groups had, on average and during the five years period, respectively 959 and 449 individuals per trap, while the other species together had 8394 individuals per trap. Major pests collected with greatest abundance were Glena unipennaria, Sabulodes caberata and Stenalcidia grosica (Geometridae) with different occurrence pattern in relation to temperature, rainfall and age of the plantation. This shows the necessity of monitoring these species during the whole growing cycle of eucalyptus plants.
\end{abstract}

Eucalyptus grandis / Lepidoptera / insect pests / climatic factors / population fluctuation

Résumé - Effet de l'âge de la plante, de la température et de la pluviosité sur les lépidoptères ravageurs d'une plantation d'Eucalyptus grandis au Brésil, d'après des captures au piège lumineux. Les espèces de lépidoptères d'une plantation d'Eucalyptus grandis ont été suivies d'août 1991 à juillet 1996 par piégeage lumineux, à Nova Era, dans l'état du Minas Gerais, au Brésil. Un total de 1385 espèces a été récolté dont 14 espèces ravageuses et 14 espèces de moindre importance. Sur les cinq années de suivi, ces deux groupes comprennent respectivement en moyenne et par piège 959 et 449 individus, tandis que les autres espèces renferment 8394 individus par piège. Les ravageurs majeurs les plus représentés sont Glena unipennaria, Sabulodes caberata et Stenalcidia grosica (Geometridae) dont la fréquence de capture varie selon la température, les précipitations et l'âge de la plantation. Cela montre qu'il est nécessaire de suivre ces espèces pendant toute la phase de croissance des eucalyptus.

Eucalyptus grandis / Lepidoptera / pestes primaires / facteurs climatiques / changement démographique

\section{INTRODUCTION}

Plantations of Eucalyptus are important for the Brazilian economy because they represent the base of an industry with revenues over US $\$ 5$ billions annually. They are also an important export item [11].

Although the main purpose of eucalyptus plantations in Brazil is to produce wood for cellulose [11] and charcoal for energy and metallurgy industry [18] the use of wood for sawtimber is increasing. However, the potential of wood production of eucalyptus plantations is constantly threatened by insect pests, including many species of Lepidoptera. Eucalyptus monocultures can favour these pests [23] and limit numbers and diver- sity of their natural enemies [22]. Outbreaks of defoliating caterpillars in eucalyptus plantations have been reported in many regions of Brazil. Several forest companies have been studying population dynamics of pest species to develop integrated pest management (IPM) programmes because it is important to know the pattern of occurrence and population fluctuation of pest species to reduce costs with labour, insecticides and equipment to control them in eucalyptus plantations [15].

The objectives of this research were to identify Lepidoptera pest species associated with a Eucalyptus grandis plantation in the Municipality of Nova Era, State of Minas Gerais, Brazil from August 1991 to July 1996 and to obtain data on the population dynamics of the major lepidopteran pest species in this area.

* Corresponding author: zanuncio@ufv.br 
Table I. Number of species (NS), individuals (IT) and individuals per species per trap (IST) of Lepidoptera (mean \pm standard error) collected in a Eucalyptus grandis plantation in the Municipality of Nova Era, State of Minas Gerais, Brazil from August 1991 to July 1996.

\begin{tabular}{lccc}
\hline Groups & NS & IT & IST \\
\hline Major important pests & 14 & $959 \pm 28.99$ & $68 \pm 2.34$ \\
Lesser important pests & 14 & $449 \pm 15.86$ & $32 \pm 1.50$ \\
Other species & 1357 & $8394 \pm 148.52$ & $06 \pm 0.15$ \\
Total & 1385 & $9802 \pm 167.98$ & $07 \pm 0.27$ \\
\hline
\end{tabular}

\section{MATERIALS AND METHODS}

Lepidopterous insects were collected at 15 days intervals between August 1991 and July 1996 using five black light traps powered by 12 volt batteries at two meters high in a plantation of $E$. grandis in the Municipality of Nova Era, State of Minas Gerais, Brazil. This area is located at $19^{\circ} 27^{\prime} 19^{\prime}$ ' South Latitude, $42^{\circ} 51^{\prime} 33^{\prime}$ ' West Longitude with an altitude of 950 meters. Mean annual temperature was $21.5^{\circ} \mathrm{C}$ and annual rainfall during this period was $1319 ; 1207 ; 954 ; 1117$ and $1103 \mathrm{~mm}$ for the five years of collection, respectively. Eucalyptus trees were three years old at the beginning of this study. A plastic bag with pieces of paper ribbon and a glass with ethyl acetate was coupled to the funnel of each trap to reduce morphological damage to insects collected [23]. These insects were sent to the Laboratory of Forest Entomology of the "Departamento de Biologia Animal" of the "Universidade Federal de Viçosa (UFV)", in Viçosa, State of Minas Gerais, Brazil where they were counted and identified by comparing them to individuals of the Museum of Entomology of the UFV and of other centres of insect identification in Brazil.

Frequency index (IF) for each major pest species was obtained with: IF $=N \times 100 / T$, where: $\mathrm{IF}=$ frequency index $(\%) ; N=$ number of individuals per pest species; $T=$ total number of Lepidoptera major pests.

Constance of each major pest species was determined with the formula of Dajoz (1973): $\mathrm{C}=P \times 100 / T$, where $\mathrm{C}=$ constance index; $P=$ total number of collections with a pest species; $T=$ total number of collections. Pest species were classified as constant (X), accessory (Y) or accidental $(\mathrm{Z})[4,8,9]$. Monthly average of total number of individuals of Lepidoptera major and lesser important pests and of those with higher numbers of individuals collected, Glena unipennaria Guenée, Sabulodes caberata Guenée and Stenalcidia grosica Schaus (Geometridae) were plotted in logarithmic scale for the five years of collection over data of temperature and rainfall to prepare the graphics.

The total number of individuals of Lepidoptera major and lesser important pests and of those of the most collected species ( $G$. unipennaria, S. caberata e $S$. grosica) were correlated with monthly mean annual temperature and rainfall during the five years of study with Pearson correlation based on a significance level of $5 \%$ with the $t$ test. The effect of age of the plantation on monthly mean annual number of individuals of primary and secondary pests species and of those with highest number to individuals collected per light trap (G. unipennaria, $S$. caberata and $S$. grosica) were evaluated with regression analysis and the model chosen was based on its significance by the F test at $5 \%$ probability.

\section{RESULTS}

A total of 1385 species of Lepidoptera were collected. Of these, 14 were classified as major pests, 14 as lesser important pests and 1357 other species with respectively $959 \pm 28.99$; $449 \pm 15.86$ and $8394 \pm 148.52$ individuals collected per light
Table II. Correlation matrix between the number of individuals of Lepidoptera major and lesser important pests species with temperature $\left({ }^{\circ} \mathrm{C}\right)$ and rainfall $(\mathrm{mm})$ in a Eucalyptus grandis plantation in the Municipality of Nova Era, State of Minas Gerais, Brazil from August 1991 to July 1996.

\begin{tabular}{lcc}
\hline Group & Temperature $\left({ }^{\circ} \mathrm{C}\right)$ & Rainfall $(\mathrm{mm})$ \\
\hline Major important pests & $-0.36^{* *}$ & $-0.50^{* *}$ \\
Lesser important pests & $0.01^{\mathrm{ns}}$ & $-0.15^{\mathrm{ns}}$ \\
\hline
\end{tabular}

** Significant at $1 \%$ probability level by the $t$ test.

ns Non significant at $5 \%$ probability level by the $t$ test.

trap during five years (Tab. I). Number of individuals of major important pests was higher during months with low temperatures $(r=-0.36, P<0.01)$ and rainfall indexes $(r=-0.50, P<$ 0.01 ) (Fig. 1 and Tab. II). However the number of individuals of lesser important pests showed no significant correlation with temperature $(r=0.01, P>0.05)$ and rainfall $(r=-0.15, P>0.05)$ (Fig. 1 and Tab. II).

The groups of Lepidoptera major and lesser important pests showed higher number of individuals when the plantation was four and five years old $(P<0.05)$ and reduced number of individuals after this last year (Fig. 2).

Most frequent collected pest species were G. unipennaria, $S$. caberata and $S$. grosica (Tab. III). These species were constant (Tab. III), indicating a pattern of more regular occurrence in the area. Other lepidopteran pest species, Eupseudosoma aberrans Schaus (Arctiidae), Sarsina violascens HerrichSchaeffer (Lymantriidae) and Blera varana Schaus (Noctuidae) were, also, constant while Eupseudosoma involuta Sepp (Arctiidae), Glena sp. and Oxydia vesulia Cramer (Geometridae) were accessories. Other pest species were considered accidentals (Tab. III).

The number of individuals of G. unipennaria did not show any correlation with temperature $(r=-0.17, P>0.05)$ and rainfall $(r=-0.16, P>0.05)$ (Fig. 3 and Tab. IV) and the frequency of individuals of this species was higher when eucalyptus plants were five and six years old $(P<0.05)$ (Fig. 4). S. caberata showed higher number of individuals during periods of low temperatures $(r=-0.40, P<0.01)$ (Fig. 3 and Tab. IV) and when eucalyptus plants were five years old $(P<0.05)$ (Fig. 4). $S$. grosica had higher incidence during periods of low temperature $(r=-0.31, P<0.01)$ and rainfall $(r=-0.34, P<0.01)$ (Fig. 3 and Tab. IV) and when plants were younger $(P<0.05)$ (Fig. 4). 
Table III. Species, number of individuals per trap and frequency and constance indexes of major Lepidoptera pests collected with light traps in a Eucalyptus grandis plantation in the Municipality of Nova Era, State of Minas Gerais, Brazil from August 1991 to July 1996.

\begin{tabular}{|c|c|c|c|}
\hline Species & Number of individuals & Frequency $(\%)$ & Constance \\
\hline Stenalcidia grosica Schaus & 273 & 28.4 & $\mathrm{X}$ \\
\hline Glena unipennaria Guenée & 163 & 17.0 & $\mathrm{X}$ \\
\hline Sabulodes caberata Guenée & 152 & 15.9 & $\mathrm{X}$ \\
\hline Glena sp. & 100 & 10.4 & $\mathrm{Y}$ \\
\hline Eupseudosoma aberrans Schaus & 98 & 10.2 & $\mathrm{X}$ \\
\hline Blera varana Schaus & 42 & 4.4 & $\mathrm{X}$ \\
\hline Eupseudosoma involuta Sepp & 36 & 3.7 & $\mathrm{Y}$ \\
\hline Oxydia vesulia Cramer & 31 & 3.2 & $\mathrm{Y}$ \\
\hline Apatelodes sericea Schaus & 23 & 2.4 & $\mathrm{Z}$ \\
\hline Sarsina violascens Herrich-Schaeffer & 22 & 2.3 & $\mathrm{X}$ \\
\hline Thyrinteina arnobia Stoll & 13 & 1.4 & $\mathrm{Z}$ \\
\hline Thyrinteina leucoceraea Rindge & 04 & 0.5 & $\mathrm{Z}$ \\
\hline Nystalea nyseus Cramer & 01 & 0.1 & $\mathrm{Z}$ \\
\hline Euselasia apisaon Dalman & 01 & 0.1 & $\mathrm{Z}$ \\
\hline Total & 959 & 100.0 & \\
\hline
\end{tabular}

$\mathrm{X}$ : constant pest species. Y: accessory pest species. Z: accidental pest species.

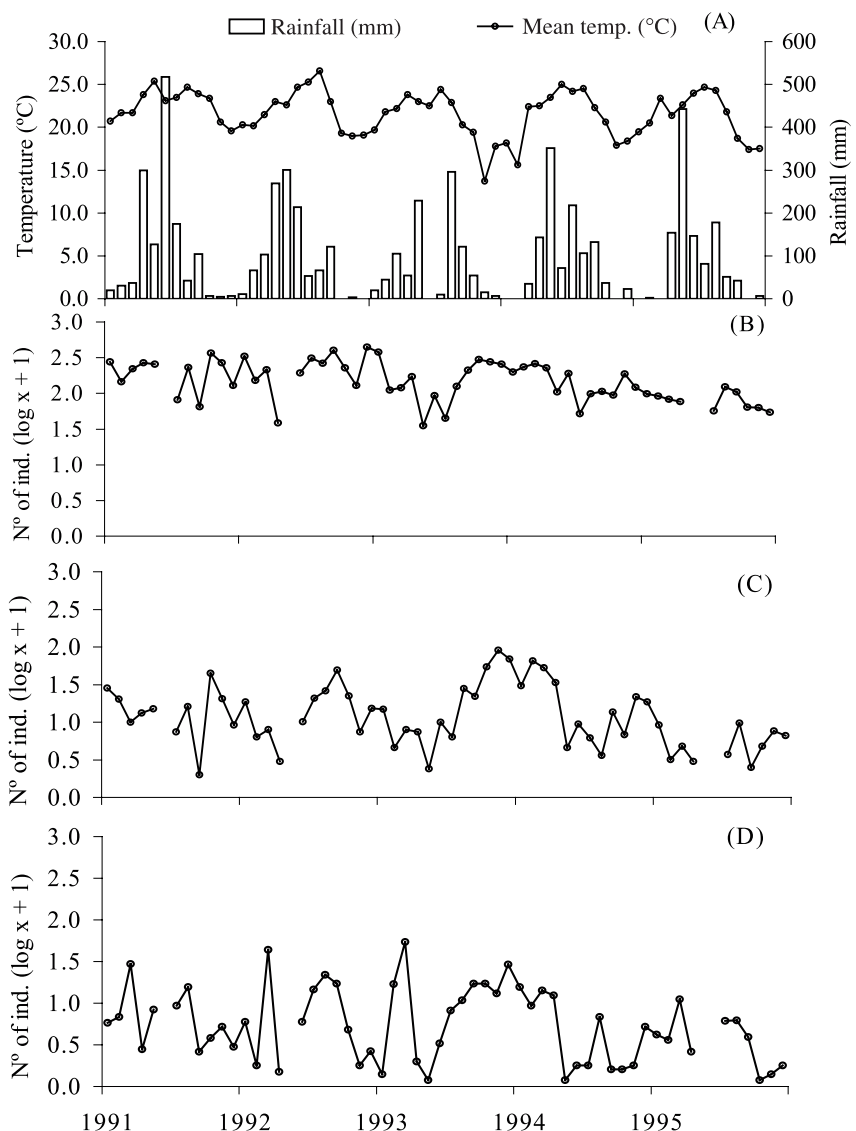

Figure 1. Mean temperature $\left({ }^{\circ} \mathrm{C}\right)$ and rainfall $(\mathrm{mm})(\mathrm{A})$ and total number of individuals of Lepidoptera (B) and of major (C) and lesser (D) important pests collected in a Eucalyptus grandis plantation in the Municipality of Nova Era, State of Minas Gerais, Brazil from August 1991 to July 1996. Discontinued lines indicated that collections were not made in these dates.

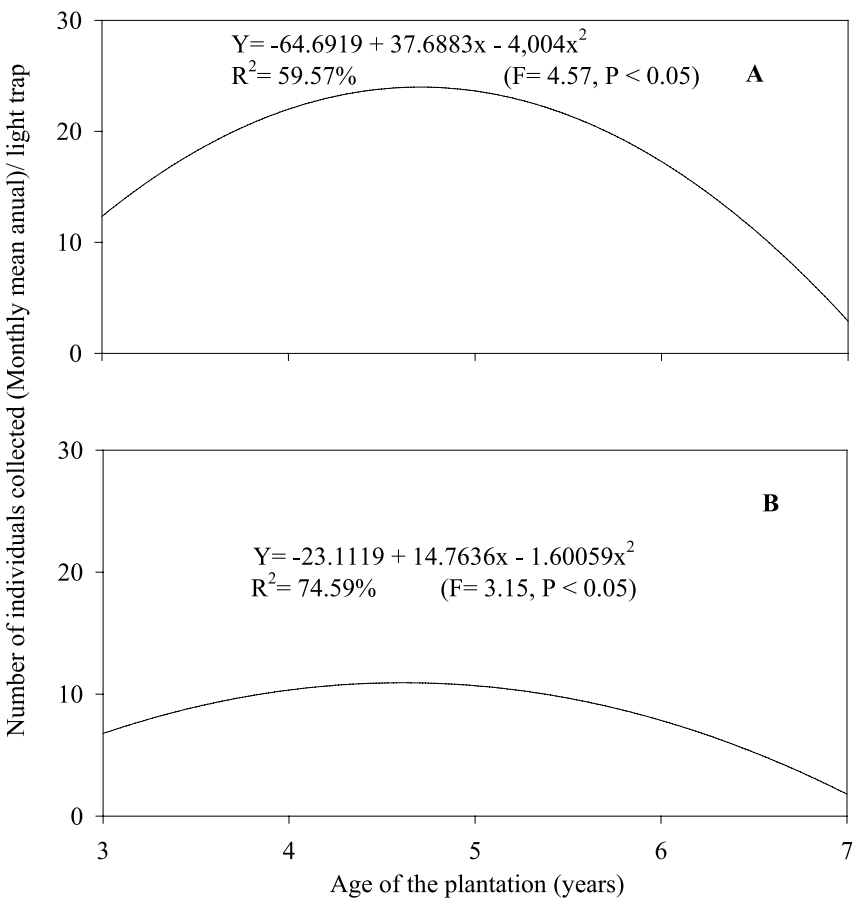

Figure 2. Regression curves adjusted as function of plant age, monthly annual number of individuals collected per light trap for Lepidoptera major (A) and lesser (B) important pests species in a Eucalyptus grandis plantation in the Municipality of Nova Era, State of Minas Gerais, Brazil from August 1991 to July 1996.

\section{DISCUSSION}

Number of Lepidoptera species collected was higher than that reported by similar studies [10, 12, 15, 25]. This suggests a larger heterogeneity of Lepidoptera species in the Municipality of Nova Era, State of Minas Gerais, Brazil. Major and lesser important pest species showed, respectively, 68 and 32 individuals per trap per species while other species presented, only 
Table IV. Correlation matrix between the number of individuals of Glena unipennaria, Sabulodes caberata and Stenalcidia grosica (Geometridae) and temperature $\left({ }^{\circ} \mathrm{C}\right)$ and rainfall $(\mathrm{mm})$ in a Eucalyptus grandis plantation in the Municipality o Nova Era, State of Minas Gerais, Brazil from August 1991 to July 1996.

\begin{tabular}{lcc}
\hline Group & Temperature & Rainfall \\
\hline Glena unipennaria & $-0.17^{\mathrm{ns}}$ & $-0.16^{\mathrm{ns}}$ \\
Sabulodes caberata & $-0.40^{* *}$ & $-0.18^{\mathrm{ns}}$ \\
Stenalcidia grosica & $-0.31^{* *}$ & $-0.34^{* *}$ \\
\hline
\end{tabular}

** Significant at $1 \%$ probability level by the $t$ test.

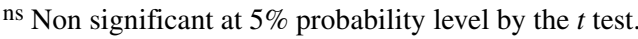
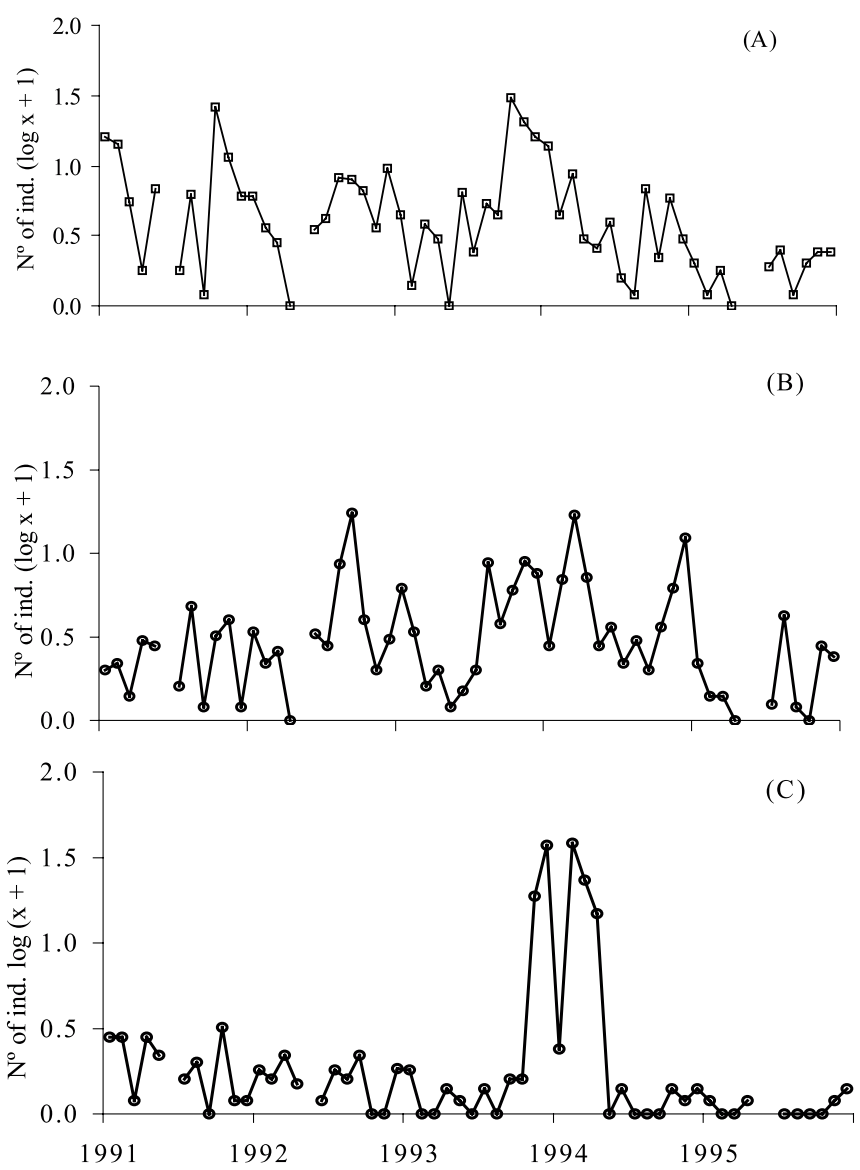

Figure 3. Monthly number of individuals of Stenalcidia grosica (A), Glena unipennaria (B) and Sabulodes caberata (C) (Geometridae) collected in a Eucalyptus grandis plantation in the Municipality of Nova Era, State of Minas Gerais, Brazil from August 1991 to July 1996. Discontinued lines indicated that collections were not made in these dates.

six individuals per trap per species. This indicates that pest species present higher specialisation and adaptation to eucalyptus plantations than other ones. Total number of individuals of major and lesser important pests was lower than other species which showed $86 \%$ of individuals collected. This indicates an adequate biological balance in eucalyptus plantations in this area with predominance of individuals of non-pest status.

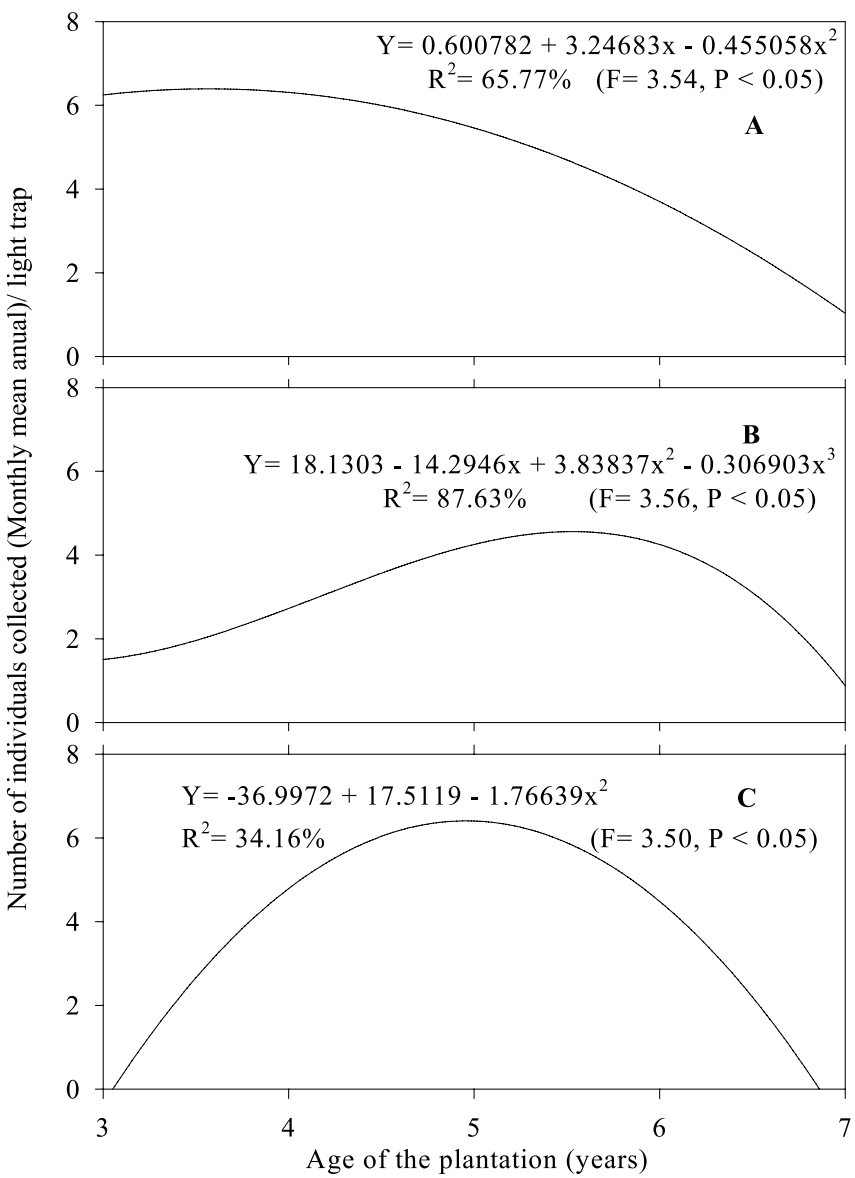

Figure 4. Regression curves adjusted as function of plant age and monthly annual number of individuals collected per light trap for Stenalcidia grosica (A), Glena unipennaria (B) and Sabulodes caberata (C) in a Eucalyptus grandis plantation in the Municipality of Nova Era, State of Minas Gerais, Brazil from August 1991 to July 1996.

These individuals may reproduce in plants of the native forest or in those under eucalyptus trees what is favoured by the fact that this plantation has about $40 \%$ of the land covered by native vegetation.

The higher number of collections of individuals of major important pest species during periods of cooler temperatures and lower precipitation is in agreement with data reported by Fragoso et al. [10], Pereira et al. [15] and Zanuncio et al. [19$21,23,24]$. The stress of eucalyptus plants during these periods, can favour the establishment of pests due to lower defence capacity of these plants [3]. These situations can hinder defence mechanisms in eucalyptus plants against herbivorous insects, which include the presence of essential oils and secondary compounds (tannins and phenols) and liberation of volatile (semiochemicals) to attract natural enemies [14]. Eucalyptus species are native to Australia, Indonesia, Papua New Guinea and Philippines [14] and they belong to the Myrtaceae family. This can explain the adaptation of insects that feeds on endemic levels in native plants in reforestations areas of eucalyptus in Brazil $[23,24]$. These native plants have coevolved with insects and they can present defence mechanisms to minimise herbivory 
while exotic eucalyptus may present low pressure against these insects [13]. For this reason it is important to maintain plantations of eucalyptus in good physiological conditions what can increase their defence systems. Lepidoptera major important pest species showed higher number of individuals during periods of low temperatures and rainfall what was different for the lesser important ones. This shows that these factors are not good indicators of occurrence of pests of this group in eucalyptus plantations.

The number of individuals of Lepidoptera major and lesser important pest species was higher when eucalyptus plants were four and five years old and with reduced numbers in the following years. This decrease may be due to the effect of natural enemies because silvicultural operations were reduced during the five years of collection what may have favoured a recovery of native vegetation around and under eucalyptus trees. Areas with larger plant diversity usually present lower number of pest species [1] because herbivores have more difficulties to find and to colonise their host plants in such conditions [22]. In addition, their natural enemies can have higher survival rates due to better pollen, nectar and alternative prey supply in these areas $[1,22]$.

Temporal distribution of the three most collected pests $G$. unipennaria, $S$. caberata and $S$. grosica was different as function of temperature and rainfall. G. unipennaria did not show any significant correlation with these factors what indicates that this species did not have a specific pattern of occurrence with temperature and rainfall and that other factors may be affecting the incidence of this pest. $S$. caberata had higher number of individuals during periods of low rainfall and adults of this species do not need humidity for emergence unlike Psorocampa denticulata Schaus (Notodontidae) [20]. S. grosica had higher abundance during periods of cooler temperatures and lower precipitation. This is important because it can allow to estimate population levels of this species in eucalyptus plantations as function of weather data and to monitor it during these periods (low temperature and rainfall).

Patterns of occurrence of eucalyptus pest species can be affected by climatic factors along time and space [2] and it can help to define periods of higher populations of these species and to reduce monitoring and control costs. Besides, it can facilitate introduction of natural enemies [23] to maintain pest populations below level of economic damage $[6,7,23]$.

Glena unipennaria is of major importance in eucalypt plantations [21] because this species and others of this genus have been damaging these plantations in Brazil. One species of this genus defoliated an area over 700 hectares in the Municipality of Antônio Dias, State of Minas Gerais, Brazil [19]. Larvae of G. unipennaria usually stay under eucalyptus leaves where they are difficult to be found due to their green color [19]. This species showed higher abundance when eucalyptus plants were five and six years old and a sharp decline on its population after this year. This may be due to the impact of natural enemies such as predatory bugs that can limit population increase of this pest [5].

Sabulodes caberata outbreaks were reported in the Municipality of Antônio Dias, State of Minas Gerais, Brazil in 1978 and in 1990 associated with Glena sp. in 400 hectares of E. urophylla $[19,21]$. Number of individuals of $S$. caberata was relatively low but the occurrence of population peaks of this species when eucalyptus plants were five years old can indicate its preference for older eucalyptus plants and it agrees to that reported for S. grosica. Sharp reduction on populations of this species after this last year may also be due to impact of natural enemies.

Stenalcidia grosica has been collected in monitoring programs in areas such as Tres Marias, Montes Claros, Ipatinga, Guanhães and Paraopeba (State of Minas Gerais), São José dos Campos, Caçapava, Guararema and Jambeiro (State of São Paulo) and Aracruz (State of Espírito Santo), Brazil sometimes in outbreak conditions [16, 19]. Caterpillars of S. grosica present high voracity. They resemble fine branches, which can difficult detection of infestations. Moreover they hang by silk threads during the first instar, which facilitates dispersal by wind. Monitoring of this species is important due to its high potential of damage [16], especially during dry and cool periods (Fig. 1). Although this species pupates in the superficial layer of the soil in organic debris [16] it does not need humidity for adult emergence. Number of individuals of $S$. grosica decreased over 5-year collection period. This suggests that it has a preference to feed on younger eucalyptus trees or the increase of natural enemies in older eucalyptus plantations $[6,7,25]$.

Preference of insect defoliators for younger or older eucalyptus plants can be due to difference in the foliage with tree age [14]. Juvenile leaves of younger trees are different from adult leaves of mature trees. Younger leaves are opposite, sessile, oval and clear green while older ones are alternated, peciolated, lanceolated and dark green. The ability of insects to use and to colonise eucalyptus plants in different growth phases can be affected by differences in surface, forms, texture and arrangement of leaves $[14,17]$. Besides they can affect the capacity of these species to use and to convert nitrogen from leaves of eucalyptus, which is an important element for metabolic activities of most defoliating eucalyptus species [14].

Reduced number of individuals of groups I and II in relation to those of non-pest species and the high diversity of Lepidoptera species show that this area presents low probability of occurrence of outbreaks of Lepidoptera pests of eucalyptus. This can be due to the fact that this area presents about $40 \%$ of the land covered by native vegetation intermingled with eucalyptus plantations. Also the impact of natural enemies can be higher in such situations which can prevent pests to reach outbreak levels.

\section{CONCLUSION}

Eucalyptus plantations in the Municipality of Nova Era, State of Minas Gerais, Brazil have a high diversity of Lepidoptera species. For this reason, outbreaks of lepidopterous pests have low probabilities of occurrence in this region. Major pests collected with highest abundance were Glena unipennaria, Sabulodes caberata and Stenalcidia grosica (Geometridae) without a common pattern of occurrence as function of temperature, rainfall and age of eucalyptus plants. This indicates that Lepidoptera pests should be monitored during the whole growing cycle to prevent damage by these pests in plantations of eucalyptus. 
Acknowledgements: To the Brazilian agencies "Conselho Nacional de Desenvolvimento Científico e Tecnológico (CNPq)", "Coordenação de Aperfeiçoamento de Pessoal de Nível Superior (CAPES)" and "Fundação de Amparo à Pesquisa do Estado de Minas Gerais (FAPEMIG)", of Brazil. To Dr William Ciesla of the Forest Health Management International for comments and reviewing the manuscript. To Prof. Adilson Oséas of the Federal University of Viçosa for preparing the French abstract.

\section{REFERENCES}

[1] Andow D.A., Vegetational diversity and arthropod population response, Ann. Rev. Entomol. 36 (1991) 561-586.

[2] Andrewartha H.G., Birch L.C., The ecological web - more on the distribution and abundance of animals, University of Chicago, Chicago, 1984

[3] Anjos N., Santos G.P., Zanuncio J.C., Pragas do eucalipto e seu controle, Inf. Agropec. 12 (1986) 50-58.

[4] Balogh J., Lebensgemeinschaften der Landtieri, Akademie Verlag, Berlin, 1958.

[5] Barcelos J.A.V., Zanuncio J.C., Santos G.P., Reis F.P., Viabilidade da criação, em laboratório, de Podisus nigrolimbatus (Spinola, 1852) (Hemiptera: Pentatomidae) sobre duas dietas, Rev. Arv. 15 (1991) 316-322.

[6] Bragança M.A.L., Souza O., Zanuncio J.C., Environmental heterogeneity as a strategy for pest management in Eucalyptus plantations, For. Ecol. Manage. 102 (1998) 9-12.

[7] Bragança M.A.L., Zanuncio J.C., Picanço M., Laranjeiro A.J., Effects of environmental heterogeneity on Lepidoptera and Hymenoptera populations in Eucalyptus plantations in Brazil, For. Ecol. Manage. 103 (1998) 287-292.

[8] Bodenheimer F.S., Précis d'écologie animale, Payot, Paris, 1955.

[9] Dajoz R., Ecologia Geral, Vozes, Petrópolis, 1973.

[10] Fragoso D.B., Zanuncio T.V., Zanuncio J.C., Filho P.J., Dinâmica populacional de lepidópteros em plantios de Eucalyptus grandis em Santa Bárbara, Minas Gerais, Rev. Árv. 24 (2000) 253-259.

[11] Gomide J.L., Utilização de madeira de eucalipto para produção de celulose e papel, Inf. Agropec. 18 (1997) 24-26.

[12] Guedes R.N.C., Zanuncio T.V., Zanuncio J.C., Medeiros A.G.B., Species richness and fluctuation of defoliator Lepidoptera populations in Brazilian plantations of Eucalypts grandis as affected by plant age and weather factors, For. Ecol. Manage. 137 (2000) 179184.
[13] Holtz A.M., Oliveira H.G., Zanuncio J.C., Costa L.R.T., Por que há surtos de insetos herbívoros em plantios de eucalipto e não em goiabas? Fol. Flor. 98 (2000) 16-17.

[14] Ohmart C.P., Edwards P.B., Insect herbivory on Eucalyptus, Ann. Rev. Entomol. 36 (1991) 637-657.

[15] Pereira J.M.M., Zanuncio T.V., Zanuncio J.C., Pratissoli D., Lepidoptera pests collected in Eucalyptus urophylla plantations during five years in Três Marias, State of Minas Gerais, Brazil, Rev. Biol. Trop. 49 (2001) 997-1006.

[16] Santos G.P., Zanuncio T.V., Zanuncio J.C., Medeiros A.G.B., Biologia de Stenalcidia grosica Schaus (Lepidoptera, Geometridae) em folhas de Eucalyptus urophylla e aspectos de sua ocorrência e controle, Rev. Brasil. Entomol. 41 (1998) 229-232.

[17] Santos G.P., Zanuncio T.V., Zanuncio J.C., Desenvolvimento de Thyrinteina arnobia Stoll (Lepidoptera: Geometridae) em folhas de Eucalyptus urophylla e Psidium guajava, An. Soc. Entomol. Brasil 29 (2000) 13-22.

[18] Valente O.F., Madeira de eucalipto como opção energética - estudo de casos, Inf. Agropec. 18 (1997) 27-52.

[19] Zanuncio J.C., Manual de Pragas Florestais, Vol. 1. Lepidoptera Desfolhadores de Eucalipto: Biologia, Ecologia e Controle, IPEF/ SIF, Viçosa, MG, Brazil, 1993.

[20] Zanuncio J.C., Alves J.B., Santos G.P., Campos W.O., Levantamento e flutuação populacional de lepidópteros associados à eucaliptocultura: VI. Região de Belo Oriente, Minas Gerais, Pesq Agropec. Brasil. 28 (1993) 1121-1127.

[21] Zanuncio J.C., Nascimento E.C., Garcia J.F., Zanuncio T.V., Major lepidopterous defoliators of eucalypt in southeast Brazil, For. Ecol. Manage. 65 (1994) 53-63.

[22] Zanuncio J.C., Mezzomo J.A., Guedes R.N.C., Oliveira A.C., Influence of strips of native vegetation on Lepidoptera associated with Eucalyptus cloeziana in Brazil, For. Ecol. Manage. 108 (1998) 85-90.

[23] Zanuncio J.C., Zanuncio T.V., Lopes E.T., Ramalho F.S., Temporal variations of Lepidoptera collected in an Eucalyptus plantation in the State of Goiás, Brazil, Neth. J. Zool. 50 (2001) 435-443.

[24] Zanuncio J.C., Guedes R.N.C., Zanuncio T.V., Fabres A.S., Species richness and abundance of defoliating Lepidoptera associated with Eucalyptus grandis in Brazil and their response to plant age, Aust. Ecol. 26 (2001) 582-589.

[25] Zanuncio T.V., Zanuncio J.C., Miranda M.M.M., Medeiros A.G.B., Effect of plantation age on diversity and population fluctuation of Lepidoptera collected in Eucalyptus plantations in Brazil, For. Ecol. Manage. 108 (1998) 91-98. 